\title{
総: 竫
}

\section{世紀末にも TURP は主役か}

\author{
北里大学医学部泌尿器科学教室 \\ 小柴健
}

CAN TURP PLAY A LEADING ROLE IN THE END OF THE CENTURY?

Ken Koshida, M.D.

Department of Urology, Kitasato University School of Medicine

\section{プロローグ}

1980年代に泌尿器科の領域で最も大きな変革をもた らした治療手段はと言えば，今では誰しもが ESWL を挙げるであろう。またその開発に主要な役割りを演 じたミュンヘンのグループが，その初期の報告を米国 泌尿器科学会に提出した際には不採用とされたといら ことはよく知られた逸話となっている。 それがまたた く間に全世界を文字通り衝撃波で包み込んでしまっ た. 1980年代はまさに ESWLで明け ESWLで暮れた と言ってよかろう。

これと同じように革命的な進歩をもたらした泌尿器 科的治療手段はといえば, 純粋に泌尿器科的療法とは 言えない人工透析療法を除けば今世紀前半の TUR と 言ってよいと思う。

1926年に Stern がループ電極を用いた最初の電気切 除鏡を考案し, 1931年に至って McCarthy が切除装置 に改良を加え，前斜視鏡を用いた Stern-McCanthy 式 切除鏡を完成させたが，これが高周波電流を用いた近 代的 TUR の始租であると言ってよかろう。これまで に数々の改良が加えられてきているとは言え，その原 型に名を取った切除鏡を半世紀以上を経過した現在に おいてもなお愛用している術者が居ることは実に感嘆 に値する.

とは言え初期のものは内視鏡の視野は狭く, 照明も 不十分で，さらに高周波電流発生装置の性能も十分と は言えず，その使用には特殊な器用さと熟練を必要と した. また今日ほどマス・メディアが発達していなかっ たこともあり，TURの普及は比較的ゆっくりであっ た. 1950年代にまず米国を席巻し，ついでョーロッパ， さらにアジアへと普及してきた。我が国での TURの 登場は1950年代の末頃であるが，本格的普及は1980年 代になってからであった。そして1990年代に入った現
在, TUR は前立腺肥大症治療の主役としての立場を ゆるざないものとし, 前立腺癌による排尿障害の除去 や早期膀胱癌の治療の分野でも不可欠な治療手段と なってきた。そればかりか現在世界的な規模で広まり つつあるェンドサージェリーのパイオニフとして，医 学の多岐にわたる分野に多大の影響を与えつつある.

その間, 数多くの薬物療法や泌尿器科的治療手段が 登場したが，いずれも根治的ないしは永続的治療効果 を期待できるまでには至らず, 前立腺肥大症治療の ターミネーターとしての TUR の評価は未だに不動で あると言ってょかろう.

またその一方で最近，TURPの予後が open prostatectomy の予後に劣るといら報告も散見されるよら になった。

このあたりで筆者の過去 30 年余の TUR 経験を振り 返り, 現状を見つめ, また将来について思らことを述 べることにする。

\section{手術器械について}

近年の急速な TUR の普及は切除鏡の改良進歩に負 らところが極めて大きい、マイクロレンズシステムの 導入により視野は明るく鮮明となり，またグラスフォ イバー導光体も細く柔軟な材質のものが出来て，ほと んど切除操作のさまたげとならなくなってきた。往時, 狭くらす暗い視野のもとで半ば模索しながら切除を進 めていったことを思うと隔世の感がある，光源には小 電球を使っていたが，もともと光量が不十分な上に， 目いっぱい明るくすると切れやすいので，やや抑㫕ぎ みの明るさにしておくが，それです 1 時間足らずの TUR のらちに 1 度ならず 2 度も切除鏡先端の小電球 を交換せねばならぬこともあり，いかに手際よく短時 間でその交換を行いらるかということも術者の技量の 1つになっていた。切除ループの材質もたしかに良く 
なった。往時 100 グラムを越す切除だと $2 ， 3$ 本は術中 に切れたループを交換したものだが，現在では大きな 腺腫の切除でも $2 ， 3$ 例に 1 度交換すればよい位であ る.これだけ切除鏡の性能が良くなってくれば, TUR 手技の習得はたしかに容易になったはずである。

しかし切除装置（working element）は 30 年以上も 前のものが未だに重用されている。前述したように Stern-McCarthy 式のものも使用されてはいるが，こ れから TUR は始める人はやはり片手操作の可能なる のを選ぶのがよいと思う。これにも多種のものがある が, 構造が複雑なものは次第に敬遠され, 極めて単純 なバネ板使用の Iglesias model が切除操作が円滑な ばかりでなく，洗滌，隇菌も容易なことから，未だに この型の切除鏡の主役の座を守り通しており，筆者も 愛用している.

概して切除鏡は軽く，小迴りがきく方が使いやすい。 重装備で大きいほど回転性能が劣ってくるばかりでな く,ループを介して指先に伝る組織を切除する際の微 妙な感じの相違が判別できなくなってしまう。こうし たこともあってか一時もてはやされた suction resectoscope む今ではあまり重用されなくなってし まった。しかし，膀胱容量の小さい患者の膀胱腫瘍切 除などには便利な道具である。

一方, 電気手術装置 (electro-surgical unit) は TUR 用器械の中でも最も大きく変化した部分と言えよう. 往時使用されたワゴンボックスタイプの真空管使用の 高周波発生装置にとって代って, ソリッドステートの ものが主流となってきた。このタイプのものは小型で 持ち運びが容易で, 術中に故障を起こすことが少なく， また切除性能も良いが，難点を挙げれば，多用途を主 眼としているためか, 凝固電流使用時にも組織が切れ ることがあるのが不安である．筆者自身は約 20 年前に 出趈っていたバーチャー社製のものが，切除の際の感 覚が良い上に，軟組織でも凝固電流で切れるというこ とがなく安全に止血操作が行えるので最も好きである が、これも現在では製造されておらず姿を消してし まったことは残念である。

潅流装置は，一時，電動式の自動供給装置が考案さ れ，筆者も使用したが，温度調節装置の部分の隇菌が 面倒なこともあって，近年では即時使用可能な状態で ビニールパックされたものをもっぱら使用している. コスト高なのが難点ではあるが，今後とも当分の間は こうした製品が重用されることと思う。

$$
\text { ティーチングシステムについて }
$$

内視鏡テレビシステムの開発が TUR 教育に果した 役割は極めて大きい，接眼部に装着するカメラは小型 化し視野も明るく大きくなり，ビデオテープに収録し て教育用に供することも普及してきた。これはスタン ダードな手技の教育の目的では如何なる教料書にも勝 ると言ってよかろう。しかしこれは初歩的な段階まで のことである.

ビデオテープに収録される TUR 画像は，さして大 きな合併症もなく，理想的に行われたものが多い，初 歩的手技の修得を一応終えた術者が独立してTURを 行うことになれば，予期せぬ大出血で視野全体が赤く 染まり，その根源が見つからずに狼狽したり，穿孔を 起こしたり，症例によっては外尿道括約筋部の識別に 苦労したり，といった事を必ずや経験するはずである. それらの対処法まで，時間をかけてビデオに収録する には大きな勇気が要ることになるばかりでなく，医師 としての倫理上の問題ともなりかねない.

はっきり言って筆者自身は現在あるようなテレビカ メラを付けてTURを行らのは好きではない，切り頃 の大きさの前立腺肥大症を，初めから順序だてて綺麗 に切り，出血も極めて少ないところを見せて得意顔を することもあるが，この程度のことは外交辞令を言っ て感心した顔を見せてくれる見学者（視察者?）にも 容易にできるはずのことであろう。

問題は TUR の可能性の限界に挑戦したり，大出血 や予期せ姶併症に遭遇した時の対処であろら，最良 の条件のもとで 1 秒を惜しんで全神経を集中せねばな らない時に，邪魔になるテレビカメラやケーブルを引 き摺りながら人に示説するほど筆者自身の心にはをだ 余裕はない，手術室に一緒に入った助手も切除鏡を 持って患者の股間に頭を埋めたまま，間断なく体や手 足を動かしている筆者の後姿をただただ見ているだけ である。しかし，その後姿を見て，術者がどのような テクニックで何をしているか判別できるようになれば 一人前の resectionist になった証拠と常に筆者は助手 達に言っている。

また症例を重ねるらちに，切除中ループから指に 伝ってくる微細な振動の相違で腺腫か線維被膜かを判 別できるようになる．また直腸内に挿入した指先で前 立腺部尿道内の切除鏡を触れることによって，どれく らいの量の腺腫が残っているか，どの程度の深さまで 更に切除を進めてよいか推測することができるし，指 先に伝わるループ振動の強弱によって線維被膜にどれ 
だけ接近しているかを知ることもできる。また閉鎖神 経反射や挙肛笳の反射的収縮の発現を肛門内に挿入し た指先で瞬時に察知して，反射的に足をペダルから離 し，穿孔や不要の切除による合併症を間一髮で防ぐ, といった手技や操作はビデオ録画を見るのみでは到底 習得しらるものではない。

中級以上の TUR 手技の習得はこれまで通り自らの 体験を通して学ばねばならず，上級者となるためには 熟達者が限界的な手技にチャレンジしている姿を数多 く脇から見て, その中から文字や影像では表現されて いない何かを汲み取って自身のものとする，といった 努力を積み重ねていくことが未だに必要だと思ってい る.

\section{とこまで切るか}

かつてその摇籃期にあっては TURP は前立腺部尿 道に排尿路を作るための, いわば姑息的治療手段で あったが，切除鏡ならびに電気手術装置の改良ととも に根治的治療手段としての評価が高まり，1950年代に は Barnes, Flocks, Nesbit らのような天才的術者に代 表されるような第 1 次黄金時代を迎えるに至った。し かし, 当時の TUR 器械は視野, 明るさともに現在のも のとは比較にならないほど劣っており，その黄金時代 は彼ら先達の天分と努力によって克ち取られたもの で，まさに“a specialty within a specialty”といら表 現1通りのものであった。一般には30グラムないしは 50 グラムを越す前立腺肥大症には open prostatectomy が適応とされ，また素質の無い者はTUR に手を出さない方がよいとまで言われていた。 それが 今日のように広く普及するまでになったのは, 器械, なかでも切除鏡の改良によるところが極めて大きい. その結果, 習熟しさえすれば 1 回の切除で100グラムを 越すようなTURPを行うことも夢ではなくなってき た.ここに至ってTURPはどのまで切るべきか, いか にして完全な切除を行らか, といら議論が再然してき た.

もともと open prostatectomy は adenectomy とも 言えるもので，主として両側葉および中葉部に形成さ れた腺腫の核出術的性格のものである。 その結果, 遺 残した前立腺組織から腺腫が再発し，排尿障害を起こ すことす少なからず見られている．また術後に前立腺 癌が発症する症例も少なからずある。一方, TUR であ れば線維被膜を残しほとんど全ての前立腺組織を切除 し去ることも可能ではある. しかし, その結果は被膜 穿孔の危険を大きくし, 静脈洞と呼ばれるような大き
な静脈が開口する頻度が高くなるばかりでなく，切断 された小動脈端は線維と線維の間に沈み込んで止血に 手間どるようになる。そればかりか, 切除され，凝固 された膀胱頝部の輪状線維や前立腺の線維被膜はやが ては硬縮を起こすことになり，厄介な後期合併症とな りかねない。

理想を言えば，前立腺の線維被膜に接した，いわゆ る外腺の部分を薄く残した状態で TURPを終えるの が結果は一番よい，最近の進歩した切除鏡をるってす るならば，解像力の優れたレンズシステムと強力な光 源のもとで, 薄く残った外腺組織の下にある線維被膜 を透して見ることもでき，それをすって resection end-point とすることも可能である.とは言っても，外 尿道括約筋に近接した前立腺尖部と, 精阜周辺の前立 腺組織は意図的に切り残しておいた方が臨床的には良 い結果が得られることが多い，外尿道括約筋に直接切 除操作が加わらないまでも，その近接部の電気凝固は 術後の一時的な尿失禁の原因となりらるし，また精阜 周辺の深追い切除は射精管を損傷して逆行性感染の危 険を多くするおそれがある。また，これらの部分には， いわゆる内腺組織は少なく，切り残しても排尿障害の 原因となるような腺腫再発の危険は極めて少ない.

では，全ての症例に理想的な TURPを行うべきか と言觉ば“否”である。るとも前立腺肥大症はかな ク大きなものであっても，排尿障害さえ無ければ早急 に切除する必要など無い疾患である。個々の患者の年 龄やリスクに応じて, 生きている間, 排尿には不自由 しないだけの切除を行いらればそれで足りるはずのも のである。また反対に，比較的若年者で射精能の保持 を希望する患者の場合には，それ相応の切除にとどめ る必要も生じてこよう，筆者はそのような患者の要望 に応じて膀胱䅡部之精阜周辺の前立腺を意困的に残 し, 排尿障害の除去に必要な程度の切除にとどめるこ とで, 逆行性射精を起こすことなく, 術後 6 年. 経過 した現在，良好な排尿能を保持している患者を経験し ている.今後はこうした患者は, あるいは balloon dilatationの適応となるか子知れない。いずれにせよ優れ た resectionist とは，短時間に大量の切院を行らだけ の術者ではなく，個々に患者のニーズに応じたTUR を安全かつ効果的に行いらる術者であると言うべきで あろう。

\section{はたしてTURPは安全か}

TURP は現在ではすでにスタンダードな泌尿器科 手術手技となり，その評価は世界的にもゆるぎないも 
のになっているが，1987年に Roos ら²)扣よび Wennberg ら³)が投じた一石は一時的にせよ大きな波紋と なって全世界に広がった。すなわち Roosらは大量の 保険請求資料の分析から TURP の再手術頻度は open prostatectomy の場合より明らかに高く，かつ予後の 面でも術後の死亡率が有意に高いことを指適した。保 険請求資料をデータベースとして医学の場に持ち込む ことの可否は別として，大きな数が漠然とながら示す 方向を一概に無視することはできない.

ついで1990年に同じグループの Malenka ら)が, 過 去の病歴の検索にもとづく分析結果でもやはり再手術 率, 術後死亡率ともに TURP が open prostatectomy に劣るという成績を報告した。

これら報告例はいずれも北米の社会医学者で, 泌尿 器科医としての主観の混らない客観的資料として貴重 なものではあるが, 泌尿器科医からは早速手厳しい反 論が加えられた。 まず Mebust $^{3 /}$ は再手術率に関して は, TURP の対象症例はもともと小さめの腺腫の症例 が選ばれることが多いので，それだけ術後に膀脱頝部 狭窄が起こりやすく，それが排尿障害の再発を招来し て再TURとなることが多いことを指摘し, Holtgrewe ${ }^{3)}$ は初回の TURP の際の腺腫の遺残をそ の原因と指摘している。しかし両者ともTURP の再 手術率が高いことには異論をはさまず当然の結果とし ている，再手術の頻度は術者の手技の優劣によっても 当然差異があるはずであるが, 高齢者や高リスク患者 には安全を第一として, 当初から当面の排尿障害の除 去を目的としたTURP が行われることも少なからず あり, これらの患者は当然排尿障害が再発することが 予想される。また，そのような患者は手術侵襲の大き いopen prostatectomy の適応とはされないといらこ とにも原因がある。再発, 再手術の可能性は高いとし ても，少ない侵襲で確実に排尿障害を治療しらること は，むしろ TURP の大きな長所とするべきであろ5.

つぎに術後の死亡率に関しては, open prostatectomyはもともと手術侵襲が大きいことから一般 状態の良好な患者が選ばれることが多く,一方 TURP は高齢者や高リスクの患者でも行いうるので, その結 果, 術後の存命率が相対的に低い数値となって現れる ことにある.したがって，これだけの数字で両者間の 優劣を論ずることはできない. Holtgrewe は“泌尿器 科医は今更時計を逆迴しにして open prostatectomy の時代に戻ることはないだろう”と述べているが，筆 者もこれには同感である.
ただし, TURP は術者の技術の優劣が患者の予後に 影響を及ぼすことも見逃すことはできない.TURPは 大量の潅流液を使用する手術であり，切除中に開口し た静脈洞から潅流液と共に血栓や微小な組織片が循環 血中に流入するおそれがあり，これが多量となれば患 者の予後に影響を及ぼす場合があると考光ねばならな い.したがって術中の患者管理が進歩した現在といえ どす，1）潅流液圧はなるべく低くとどめる，2）静脈 洞開口を起こすことの多い前立腺線維被膜に及ぶ切除 はできるだけ避ける，3）静脈洞開口を認めたら速やか にTURを終了し, バルーン・カテーテルによる圧迫止 血をはかる，4）TUR 施行時間はなるべく短かくとど める,といった基本的注意事項を遵守すべきであろう.

また, TURP の再手術率が高いことはむしろ当然と 受け止めるべきであろう．患者のリスクに応じた安全 な TURPを行らことを第一とし，輸血も極力避ける べきであろう，不完全な切除を危惧するよりは，患者 の安全を重んじて途中で止めることるできる TURP の長所をより尊重すべきであろう.

$$
\text { エピローク }
$$

21世紀にはTURPはどうなっているであろらか.

TURP には特異な魅力がある. 技量がある程度の域 に達すると手術しているのが楽しくなる，順調に切除 が進み, 出血も少ない時には鼻歌の 1 つも出てこよう といらすのである。 また椅子に座りながら，1時間前 後で終えらることも大きな長所である. Barnesや Flocks らむかなり高秢になるまでTURを続けてい たが，眼と指先の動きさえ確かなら，70歳以上になっ ても術者となることも可能であろう。これからは医師 自身も高龄化社会の一員となることでもあり，それに 対処する上にも好ましい手術であると言える。しかし， その楽しみもそう長くは続かず，せいぜい今世紀末ま でであろう．21世紀には多分機械が手術の主役となる のではないかと思5。あらかじめ正確に計測された前 立腺を，特殊なセンサーを備えた手術機械が，あらか じめコンピューターに入力されたプログラム通りに必 要なだけの切除を行い, 止血も同時に行われることに なるだろう。こうなれば機械の良し悪しが結果の良し 悪しにつながることになり, 個々の泌尿器科医の存在 感や満足感など介在する余地は無くなってしまらこと だろう。他の分野の先端医療の開発の分野も理工学系 の人達がその主役の座に着くことになり，20世紀後半 の泌尿器科医にとっては何とも味気ない時代になるの ではないかと思う。 


\section{文 献}

1) Barns, R.W., Bergman, R.T. and Hadley, H.L.: Endoscopy. Springer, Heidelberg, 1959.

2) Roos, N.P. and Ramsey, E.W.: A populationbased study of prostatectomy: outcomes associated with differing surgical approaches. J. Urol., $137:$ 1184, 1987.

3) Wennberg, J.E., Roos, N., Sola, L., Schori, A. and Jaffe, R.: Use of claims data systems to evaluate health care outcomes. Mortality and reoperation following prostatectomy. J.A.M.A., 257, 933, 1987.

4) Malenka, D.J., Roos, N., Fisher, E.S., McLerran, D., Whaley, F.S., Barry, M.J., Bruskewitz, R. and Wennberg, J.E.: Further study of the increased mortality following transurethral prostatectomy: A chart-based analysis. J. Urol., 144, 224, 1990. 